Editon Consortium Publishing

Transforming Scholarly Publishing
Editon Consortium Journal of Kiswahili

(ECJKISW)

Volume: 01 Issue: 01 | April -2019

ISSN: $2663-9289$

www.editoncpublishing.org

Githinji, D. G.; Lihanda, M. K., Editon Cons. J. Kiswahili. Double-Blind Peer Reviewed Journal

\title{
The Influence of School Resources on Instruction of Kiswahili Grammar in Baringo Central Sub-County
}

\author{
Damaris Gakii Githinji'; Milton Kigaro Lihanda² \\ Department of Curriculum, Instruction \& Educational Media, Moi University \\ Corresp.Author Email: dagagi72@gmail.com
}

IKISIRI/ABSTRACT:

The study set out to investigate how school resources influence the instruction of Kiswahili grammar in Baringo Central Sub-County. Kiswahili is among the core subjects taught in secondary schools curriculum in Kenya. It is the official and national language in the Republic of Kenya. There, however, have been several challenges affecting the subject in schools. From the study, it was established that $66.7 \%$ of sampled schools lacked the necessary teaching and learning resources like library and classes hence impeding academic achievement. The study will be useful in helping school authorities, the Ministry of Education, County authorities and other stakeholders to understand the role played by resource availability in facilitating the instruction of Kiswahili grammar in Baringo Central Sub-County. It recommends that the Ministry of Education, school authorities, County authorities and other stakeholders should provide enough facilities and resources for teaching and learning like libraries and classrooms.

Key Terms: School resources, Kiswahili grammar, instruction.

$* * *$

How to cite this article in APA ( $6^{\text {th }}$ Edition):

Githinji, D. G., \& Lihanda, M. K. (2019). The influence of school resources on instruction of Kiswahili grammar in Baringo Central Sub-county. Editon Cons. J. Kiswahili., 1(1), 1-13. $* * *$ 


\section{Editon Consortium Journal of Kiswahili (ECJKISW)}

Volume: 01 Issue: 01 | April -2019

ISSN: $2663-9289$

www.editoncpublishing.org

Githinji, D. G.; Lihanda, M. K., Editon Cons. J. Kiswahili. Double-Blind Peer Reviewed Journal

\section{Utangulizi/Introduction}

Kiswahili as a language has improved in its usage in Kenya since independence through the academic achievement in most parts of the country has been below average. The Constitution of the Republic of Kenya [1], entreanched Kiswahili as both national and official language. Ogechi [2] states that Kenya is multilingual and multiracial; however, it is difficult to say the exact number of codes used. This means that though the main reason for choosing Kiswahili as a national language was to attain cohesiveness and identity, the goal has not yet been achieved.

Owing to multilingualism situation in Kenya at independence, Kenya needed a language that would unite all people. Kasfir [3] argues that though language is just one characteristic for identifying an ethnic group, in the Kenyan context, it is crucial marker of an ethnic group. National integration requires a country to have a national language for it to be achieved. Thus, the introduction of Kiswahili became a vehicle for not only national unity, but also an avenue for preservation, transmission, and development of African culture. Allan [4] argues that a country without a national language has nothing to be proud of as a nation.

Thus, for Kiswahili to be used effectively by all and be taken as a national language, there was need to teach it in schools. According to ROK [5], the Ominde Commission recommended for the general spread of Kiswahili language, has the capacity to not only to provide an extra and specific vehicle for national unification and coordination, but also to enhance communication internationally both within East Africa and the Eastern part of Congo (Zaire) and part of Central Africa.
The government of Kenya, through the Education Commission, recommended the teaching of Kiswahili as part of the Africanisation of the curriculum to make it responsive to African culture [6]. Sayoum [7] notes that indigenous languages do reflect learners' background or addresses their needs while positively influencing their educational achievements. In that regard, they are practical, relevant, and necessary for the revival of Africa's institutions. The introduction of Kiswahili therefore, not only acted as a vehicle for national unity but also as an avenue for transmission, preservation and development of African culture. The Kenya bilingual system of education thus needs to address itself to the question of who learns a second language more efficiently, more quickly and with better retention if the expected output in competence in the languages targeted by the systems is to be achieved [8].

In Kenya, a pupil joining school has at least competence in his/ her mother tongue or first language, and at times English or a home variety of Kiswahili. According to the theory of Language Teaching and Learning by Bloom [9], the level of language that a person acquiring it gets, is determined by how much exposure one gets in his or her immediate environment and how much of that language one interacts with in terms of speaking it and being spoken to by others.

There are many reasons why individuals learn a second language which comprises several motivations. One such motivation is cultural awareness whereby learning a second language helps to collapse national ethnic and stereotype barriers and subsequently creates intercultural sensitivity and awareness. Indeed, language has the power to foster improved understanding between people of various cultural backgrounds. This is because culture is embedded in language and increasing cultural sensitivity is vital as the world becomes more of a global village. 


\section{Editon Consortium Journal of Kiswahili (ECJKISW)}

Volume: 01 Issue: 01 | April -2019

ISSN: $2663-9289$

www.editoncpublishing.org

Githinji, D. G.; Lihanda, M. K., Editon Cons. J. Kiswahili. Double-Blind Peer Reviewed Journal

The second motivation for second language learning is traditional bias. This is the learning of a language for general educational and academic value. In the current Kenyan language policy, Kiswahili is a compulsory and examinable subject in both primary and secondary school. This means that a good grade in Kiswahili is a requirement for upward mobility in education and in career choice and development. Indeed a student joining the university is required to have an average mark and above, that is $\mathrm{C}^{+}$, either in English or Kiswahili. Subsequently, all the public primary and secondary schools teach Kiswahili alongside English as compulsory and examinable subjects. This language policy together with the need of career choice has made Kiswahili get more attention from the teachers and the learners just like any other examinable subject. For one to do well in Kiswahili examination at the national level, the grammar section is very vital.

Those who argue for grammar teaching posit that some focus on 'form' may as well be necessary if many students are to achieve accuracy and fluency in their acquisition of a second or foreign language. Given that the main purpose of learning language is to use it as a mean of communication makes grammar essential. However grammatical competence is not communicative competence. Communicative competence consists of the knowledge on how to correctly use the grammar and vocabulary of a language to achieve communication objectives as well as knowing how to do this in a socially appropriate manner. Communicative goals are the goals of students studying Kiswahili language. Therefore teaching grammar is necessary to achieve the goals.

However, for several years (2009-2013), the performance of students who sat the Kenya Certificate of Secondary Education (KCSE) and the Kenya Certificate of Primary Education (KCPE) in Kiswahili subject has generated much concern because of the perennial poor results. In contrast to this, Kiswahili objectives for both secondary and primary schools in Kenya expect learners to be able to read with comprehension, to express themselves logically, clearly, and coherently in writing and speech; to listen with understanding and to communicate appropriately; among others things, at the end of their various courses [10].

Over these years; 2009-2013, student performance in KCSE Kiswahili Paper 2 which examines in part, grammar, in the national Kiswahili examinations ran by the Kenya National Examinations Council (KNEC) continued to drop painting a grim picture on the future of this language in Kenya.

KNEC [11] in its KCSE analysis recommended that teachers should get a lasting solution to Kiswahili performance as they cite the grammar section as the poorest performed over the years in Kiswahili paper two. With this in mind, the researcher seeks to investigate school factors which may be contributing to this under-achievement. These factors include physical resources and facilities, teacher staffing, teachers and students attitude towards grammar. These factors act as inputs in education whereas achievement is the output.

To achieve the goals of education, language is viewed as an agent of national unity. Kenya at independence adopted Kiswahili as her national language. This led to Kiswahili being included in the school curriculum as a subject. Thus, being a teaching subject, it is worth noting that Kiswahili is also a growing and dynamic language. With Kenya being a competitive society, minimum entry requirements into various courses in higher institutions of learning have gone up. A mean grade of $C+$ is required for entry into a Degree program. This indicates that the learners who underachieve in Kiswahili affect their aggregate mean score since Kiswahili is a compulsory subject in K.C.S.E. Baringo Central sub-county was the focus of study in which Kiswahili performance was below average. There is, therefore, need for a lasting solution to the under-achievement in Kiswahili in Baringo central sub-county as it shows that very few 


\section{Editon Consortium Journal of Kiswahili (ECJKISW)}

Volume: 01 Issue: 01 | April -2019

ISSN: $2663-9289$

www.editoncpublishing.org

Githinji, D. G.; Lihanda, M. K., Editon Cons. J. Kiswahili. Double-Blind Peer Reviewed Journal

students attain the average grade required for enrolment in institutions of higher learning.

\section{Methodology}

The study adopted a descriptive survey design. The study was conducted in public secondary schools of Baringo subCounty-Kenya. The area was ideal for the study because Kiswahili achievement was low between the years; 20102014 under study compared to its neighbors. The target population comprised all form four students, all teachers of Kiswahili and all the school principals in Baringo central sub-county. Stratified random sampling method was adopted in selecting the percentage of schools that were included in the study because the county had single and mixed gender, extra-county, county and sub-county schools which were either day or boarding.

Two strata sampling were applied for the study including first, gender status of the school and second; the size of the school as per the number of students in each class. Using 30\% recommended by Mugenda and Mugenda [12] as enough representative of target population, 12 public secondary schools (33\%) that had done KCSE between 20102014 were selected using stratification method as follows: two boys boarding out of five, two girls boarding schools out of six (6) and 8mixed day secondary schools out of twenty-five (25). Specific schools in the strata were selected using simple random sampling. Twelve (12) classes were used in the study where an equal number of students (20) were selected through probability sampling using raffles, (folding of papers which were labeled Yes and No). Students picked, and those with 'Yes' were included in the study from each of the form four classes.

In schools with than one stream, random sampling was used to select one stream to be used in the study. Two teachers of Kiswahili from the two (2) boys schools, two teachers of Kiswahili from two (2) girls school and one(1) teacher of Kiswahili from each of eight (8) mixed day schools were selected through purposive sampling to get teachers of Kiswahili teaching form four classes. One principal from each of the 12 schools was selected using purposive sampling.

The researcher applied the use of two instruments for the study which include interview schedule for principals and questionnaires for both teachers and students. The data collected was appropriately coded and entered into the computer for analysis. Qualitative data obtained was analysed thematically. Data was organised into themes, categories and patterns relevant to the study; then the findings were presented through tabulation. Quantitative data obtained was coded then analysed with the help of Statistical Package for Social Sciences (SPSS), and the results from the analysis were presented using percentages, means, frequency distribution tables, bar graphs, and pie-charts. Findings were reported thematically based on the research objectives.

\section{Literature Review \\ School Facilities and Resources}

a) Physical Facilities

Developing and maintaining physical facilities in educational institutions by parents, communities, and sponsors should continue to be encouraged. This is because the lack of such facilities interferes with the learning process [13]. From the research carried out elsewhere in the world, school facilities have been found to be critical concerning quality education. Difference in school facilities is seen to account for the difference in achievement. These physical resources may include classrooms, auditoriums, lecture theatres, laboratories, workshops, administrative block, libraries, playgrounds, assembly halls and special rooms like a clinic, students' hostels, staff quarters, kitchen cafeteria and washroom. 


\section{Editon Consortium Journal of Kiswahili (ECJKISW)}

Volume: 01 Issue: 01 | April -2019

ISSN: $2663-9289$

www.editoncpublishing.org

Githinji, D. G.; Lihanda, M. K., Editon Cons. J. Kiswahili. Double-Blind Peer Reviewed Journal

Learning experiences tend to be fruitful where there are adequate quality and quantity of physical resources. Conversely, unattractive school buildings, non-availability of playing grounds, crowded classrooms, and surroundings that lack aesthetic beauty have been found to contribute to poor academic performance. To emphasise further on the issue of physical facilities, there is need to develop appropriate and adequate physical facilities for quality education to be realised.

Sallis [14] indicates that even with the teachers trained and committed, policy guidelines alone cannot be adequate for effective implementation of an educational program if appropriate and adequate physical facilities like classrooms, toilets and playground are not provided. MOEST [15] explains the importance of ensuring that there are adequate and appropriate facilities for teachinglearning so that educational programs could be implemented effectively. Schools with adequate classrooms, for instance, conduct their lessons outside or under trees. On days with unfavourable weather such lessons are either postponed or are never held at all. This interferes with the coverage of the syllabus and students from such schools usually do not perform well in the examination. ROK [16] states that Kenya schools are characterised by a variety in the quality and size of buildings.

Some schools may share classrooms and science laboratories, which are often too small for current classes of forty and above students. Some new schools, on the other hand, have teaching rooms which are also small because they were not built to specifications. Additionally, most schools do not properly maintain their buildings and other facilities. Such facilities impede the teaching and learning process and eventually affect students' performance in examinations.
There should be sufficient coherence between the supply and distribution of resources, buildings and equipment and lack of rooms, financial and material resources and equipment, and the delay in procurement and late delivery may hinder innovation and subsequent performance. Musau [17] established that the lack of library facilities was one of the most serious challenges preventing the achievement of high education standards in learning institutions.

Ayoo [18] carried out a study on the effects of school physical facilities on academic performance and established that the availability of facilities had a direct link with the performance of learners' examinations. Students in schools that have adequate physical facilities perform better than those that do not have adequate physical facilities. Raju [19] in his study on education in Kenya observed that schools were poorly equipped in the rural areas. There was a lack of suitable teaching aids and poor teaching facilities and this negatively related to performance. This could be attributed by the inception of free primary and secondary education which has in the years led to high admissions in schools thus overcrowding in classes.

According to the presidential working party on education and Manpower Training for the next decade and beyond, ROK [20] in Kamunge Report, school learning resources should be appropriately planned for and effectively utilised to bring about efficient provision of quality and relevant education. Mworia [21] found out that some schools lacked enough classrooms, desks and chairs leading to overcrowding and such conditions frustrated students during learning. Mutua [22] in his study on the importance of learning facilities established that many schools in MtitoAndei Division were ill-equipped and they lacked the essential physical facilities necessary for learning. Kathuri [23] further notes that better facilities in a school lead to better performance in examinations. This is witnessed in 


\section{Editon Consortium Journal of Kiswahili (ECJKISW)}

Volume: 01 Issue: 01 | April -2019

ISSN: $2663-9289$

www.editoncpublishing.org

Githinji, D. G.; Lihanda, M. K., Editon Cons. J. Kiswahili. Double-Blind Peer Reviewed Journal

KCSE results whereby equipped schools perform better than those that are not fully equipped.

\section{b) Instructional resources}

Instructional resources in terms of educational inputs are of vital to the teaching of any subject in the school curriculum, and the use of instructional resources would make discovered facts glued firmly to the memory of students. Imaginative and well-planned use of visual Aids in a lesson should do much banish apathy, arouse student's interest by giving them something practical to see and do as well as supplement inadequacy of books, while at the same time helping to train them to think things out themselves at the same.

On the other hand, scarcity of textbooks, libraries and physical facilities will constrain educational system from responding more fully to new demands. Better learning materials and resources are needed to raise the quality efficiency and productivity of education.

It is crucial to have appropriate personnel plan and adequate instructional materials and physical facilities to support the educational effort. Material resources include textbooks, charts, maps, audio-visual and electronic instructional materials such as radio, tape recorders, television and video tape recorder. Other categories of material resources consist of paper supplies and writing material such as pens, eraser, exercise books, crayons, chalk, drawing books, notebook, pencil, ruler, slate, workbooks and so on. Newton [24] professed that the magnitude of instruction is more scientific based, makes learning more immediate; makes teaching more powerful; and finally ensures equality in access to education.

Adeogun [25] discovered a powerful positive significant relationship between instructional resources and academic performance. According to him, Schools endowed with more resources performed better than schools that are less endowed. He discovered a low level of instructional resources available in public schools and stated that Kenya's public schools are starved of both learning and teaching resources. He expressed that effective teaching cannot take place within the classroom if basic instructional resources are not present.

Textbook and resource materials are fundamental tools for effective teaching and learning. Absence or inadequacy of these materials makes teachers handle subjects abstractly, portraying it a dry and non-existing [26]. In addition, Ayot and Briggs [27] point out that poor results in education relate to the number of resources and instructional materials allocated.

\section{c) School environment}

The quality of a school's environment and its facilities has an influence on students learning. Besides regular use in organising and managing schools activities, records of school physical facilities and materials resources such as equipment and furniture can provide data to drive many indicators for assessing the quality of education in a school.

Mohammed [28] observes that the school environment is of paramount importance in promoting learning. Research has shown that factors closer to students' actual learning process have the most definite impact. WanyHaertel and Walberg [29] argue that school environmental factors have an impact than more distant factors such as administrative characteristics of the education systems at the national level.

Dorman [30] Postulates that school physical resources refer to school physical structure, equipment, other teaching and learning resources and class size among others. The environment in an educational setting refers to the emotional atmosphere, tone, ambience or climate that prevails in a particular context. Nijihuis [31] states that school environment is of paramount importance to 


\section{Editon Consortium Journal of Kiswahili (ECJKISW)}

Volume: 01 Issue: 01 | April -2019

ISSN: $2663-9289$

www.editoncpublishing.org

Githinji, D. G.; Lihanda, M. K., Editon Cons. J. Kiswahili. Double-Blind Peer Reviewed Journal

promote learning. The type of atmosphere prevailing in school is an endless inspiration for the children to learn more and more.

Classroom environment is the total of all social, emotional, mental and physical factors that make an overall contribution to the teaching-learning process within a classroom. According to Goddard [32], a favourable learning environment improves academic and professional standards of the school and leads to higher achievement. Scheerens [33] argued that the availability of teachinglearning resources enhances the effectiveness of the school as they are primary factors that can result in excellent academic performance.

Febummi and Okore [34] further add that class factors are critical in the teaching-learning activities mainly when students' academic performance is being considered. He adds that class size is an important factor with the academic performance of students. There is a consensus among various resources and educationists that, the lower the class size or teacher-student ratio, the higher the achievement and those students' achievement decreases as class size increases. Because of this fact, it could be said that teacher-pupils ratio is one of the important factors determining good academic achievement.

\section{Theoretical Framework}

The study adopted the Production Function theory of education as its guide. This theory is similar to Input-Output theory postulated by Fred C Lunenburg in 2008. The production function theory of education advances that a school is seen as a firm which receives inputs (students, facilities, resources, teachers') and transforms them into educational outputs through a process. Input refers to something put into a system or expended in its operation to achieve a particular output or a result. The output is the information or data produced by a process or system from a specific input. In the context of systems theory, the inputs are what is put into a system and outputs are the results produced after running an entire stipulated process. Since the outputs can be the results of an individual unit of a larger operation, thus outputs of one part of a process can be the inputs to another part of the process.

Education according to Coombs [35] consists of two components: inputs and outputs. According to Coombs, inputs include of human and material resources, and outputs are the goals and outcomes of the education process. Both the outputs and inputs form a dynamic organic whole, and anyone who wants to assess and investigate the educational system for improving its performance must examine the effects of each of these components.

This theory had been used by several authorities such as Coleman [36] and Fuller [37] in an attempt to measure the contribution of various factors of educational output. The production function theory of education measures output (student achievement) by standardised achievement test scores

Education is a service which transforms fixed quantities of input (i.e. individuals) into individuals with different quality attributes, to enable students to cope with and perform in society after they have left schooling. The theory explains how student achievement (outputs) is dependent upon school inputs such as teaching and learning resources, staffing and qualification of teachers, school language policies as well as the school administration. A school receives input, that is, students, teaching personnel, teaching and learning resources and instructional materials. A particular process of transformation that is, teaching and learning takes place where skills in Kiswahili language practices are disseminated to students. The process is guided by teachers who utilise their academic and professional, qualifications, teaching experience and school language policies to influence student language 


\section{Editon Consortium Journal of Kiswahili (ECJKISW)}

Volume: 01 Issue: 01 | April -2019

ISSN: $2663-9289$

www.editoncpublishing.org

Githinji, D. G.; Lihanda, M. K., Editon Cons. J. Kiswahili. Double -Blind Peer Reviewed Journal

usage, development of the right attitudes towards Kiswahili and proper time management. This results in high output (student achievement) measured through high grades and competence in Kiswahili grammar. In this study, the school factors will be the inputs while students' achievement will be the outputs.

The literature reviewed literature shows that student achievement in Kiswahili language at the national examination (KCSE) is heavily influenced by variables such as school facilities and resources, Staffing of Kiswahili teachers, Teachers and students perceptions towards Kiswahili grammar. It is discouraging that the performance of Kiswahili has been below average even though it is an African language though taught in schools as a second language. From the literature reviewed, it was noted that school facilities and resources play a critical role in determining instruction of Kiswahili grammar, but more needs to be done to evaluate whether or not schools have the required capacity in terms of teaching /learning facilities and resources.

\section{RESULTS AND DISCUSSIONS}

Sampled Schools' Performance in Kiswahili between 2010 and 2014

Kiswahili performance at KCSE for the period 2010 to 2014 is summarised as indicated in Table 1.

Table 1: Kiswahili KCSE means scores, deviations and their percentages in sampled schools.

\begin{tabular}{|l|l|l|l|}
\hline $\begin{array}{l}\text { KCSE } \\
\text { Year }\end{array}$ & $\begin{array}{l}\text { Mean } \\
\text { score }\end{array}$ & Deviations & $\begin{array}{l}\text { (\%) } \\
\text { Deviation }\end{array}$ \\
\hline 2014 & 5.28 & $+\mathbf{+ 0 . 5 2}$ & $\mathbf{1 0 . 9 2}$ \\
\hline 2013 & 4.82 & +0.06 & 1.26 \\
\hline 2012 & 4.495 & -.265 & 5.57 \\
\hline 2011 & 5.073 & +0.313 & 6.576 \\
\hline
\end{tabular}

\begin{tabular}{|l|l|l|l|}
\hline 2010 & 4.11 & -0.65 & 13.6 \\
\hline
\end{tabular}

Source: Baringo central sub-county CQASO Office - KCSE Result Analysis 2014

The results in Table 1 show that the performance of Kiswahili in Baringo central Sub-county over the five years under study has not been encouraging despite the positive deviations. This has been so because majority of the schools (66.67\%) are day schools that attract students with low entry behaviour from primary, have inadequately trained teachers, have inadequate teaching and learning resources among others, while the remainder (33.33\%) are extra-county which admit students with higher entry behaviour, have better Instructional resources and trained teachers.

Table 2: Kiswahili performance from $2010-2014(n=12)$

\begin{tabular}{|l|l|l|l|}
\hline $\begin{array}{l}\text { Mean } \\
\text { range }\end{array}$ & Midpoint(x) & $\begin{array}{l}\text { Frequency } \\
\text { (f) }\end{array}$ & Fx \\
\hline $2.1-3.0$ & 2.6 & 0 & 0 \\
\hline $3.1-4.0$ & 3.6 & 6 & 21.6 \\
\hline $4.1-5.0$ & 4.6 & 1 & 4.6 \\
\hline $5.1-6.0$ & 5.6 & 1 & 5.6 \\
\hline $6.1-7.0$ & 6.6 & 1 & 6.6 \\
\hline $7.0-8.0$ & 7.6 & 3 & 22.8 \\
\hline $8.1-9.0$ & 8.6 & 0 & 0 \\
\hline & $\sum \mathbf{f = 1 2}$ & $\begin{array}{l}\sum X=61.2 \\
\text { MEAN SCORE 5.1 }\end{array}$ \\
\hline
\end{tabular}

From the results indicated, the average mean of Kiswahili for the sampled schools for the years 2010, 2011, 2012, 2013 and 2014 was 5.1 average of a C-. The C- mean score was below the required $C+$ for entry into institutions of higher learning like universities. 


\section{Editon Consortium Journal of Kiswahili (ECJKISW)}

Volume: 01 Issue: 01 | April -2019

ISSN: $2663-9289$ www.editoncpublishing.org

Githinji, D. G.; Lihanda, M. K., Editon Cons. J. Kiswahili. Double-Blind Peer Reviewed Journal

School resources affecting performance in Kiswahili

The researcher sought to find out the impact of school physical resources that influence the instruction of Kiswahili grammar. Such resources included instructional resources, school physical facilities, class size among others. Teachers were thus asked to give their views on resources that influenced their instruction work, and they responded as shown in table 3 .

Table 3: Teachers views on facilities and resources influence on performance $(n=15)$

\begin{tabular}{|l|l|l|}
\hline $\begin{array}{l}\text { School } \\
\text { resources }\end{array}$ & Frequency & $\begin{array}{l}\text { Percentage } \\
(\%)\end{array}$ \\
\hline School facilities & 7 & 46.6 \\
\hline $\begin{array}{l}\text { Instructional } \\
\text { resources }\end{array}$ & 14 & 93 \\
\hline $\begin{array}{l}\text { School } \\
\text { environment }\end{array}$ & 13 & 86.7 \\
\hline
\end{tabular}

The results in Table 3 indicate that 14 out of 15 teachers, representing $93 \%$ considered instructional resources as a major factor responsible for the dismal performance. Other factors were school physical facilities school management styles $46.6 \%$, and school environment constituting $86.7 \%$. School physical facilities especially classes had a bearing on performance according to school principals. It was found that schools had varied class sizes: $25 \%$ of the schools had between 31 and 40 , the next $66.67 \%$ of the schools between 41 and 50, while the remainder $8.33 \%$ between 50 and 60 students. Other County schools accounting for $25 \%$ did not have enough classrooms due to high enrollment thus had congested classes which made it impossible for teachers to attend to individual student needs.

The results indicated that school environment had an impact on school performance as indicated by $86.7 \%$ of teachers. This was because some schools were inaccessible especially during rainy seasons as teachers found it a challenge to make it to school in time and left earlier in the evening leading to loss of many human hours. Students were also asked to give their views on instructional resources and responded as indicated in table 4 .

Table 4: Students' responses on availability of instructional resources (n-229)

\begin{tabular}{|l|l|l|}
\hline Response & Frequency & Percentage (\%) \\
\hline Yes & 63 & 27.5 \\
\hline No & 166 & 72.5 \\
\hline Total & $\mathbf{2 2 9}$ & $\mathbf{1 0 0}$ \\
\hline
\end{tabular}

The information in table 4 indicates that majority of students representing $72.5 \%$ confirmed that their schools lacked enough instructional resources, while $27.5 \%$ of the students were of the view that their schools had enough teaching and learning resources. The findings demonstrate that majority of the learners $72.5 \%$ ) who were mainly drawn from county day schools felt that their school authorities were not doing enough to purchase the relevant books, while the remainder (27.5\%) belonged to three extracounty schools which were able to provide the necessary instructional facilities apart from having a higher enrollment.

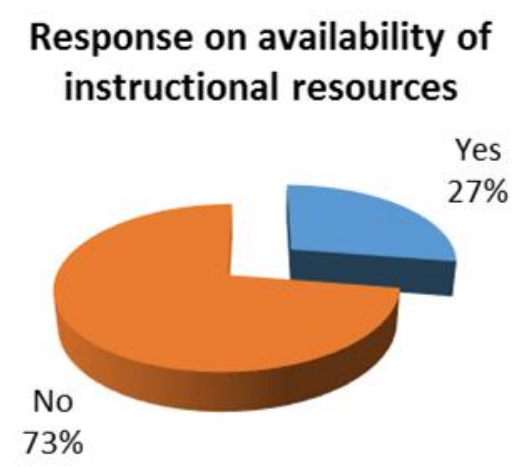

Figure 1: Students response on the availability of resources On the use of the available books in sampled school, students had the following varied reactions as illustrated in table 5 . 


\section{Editon Consortium Journal of Kiswahili (ECJKISW)}

Volume: 01 Issue: 01 | April -2019

ISSN: $2663-9289$

www.editoncpublishing.org

Githinji, D. G.; Lihanda, M. K., Editon Cons. J. Kiswahili. Double-Blind Peer Reviewed Journal

Table 5: Students proportion on the sharing of the available books $(\mathrm{n}=229)$

\begin{tabular}{|l|l|l|}
\hline $\begin{array}{l}\text { Books ratio } \\
\text { among learners }\end{array}$ & Frequency & Percentage (\%) \\
\hline 1 between 2 & 43 & 18.7 \\
\hline 1 between 3 & 51 & 22.3 \\
\hline 1 between 4 & 135 & 59 \\
\hline Total & $\mathbf{2 2 9}$ & $\mathbf{1 0 0}$ \\
\hline
\end{tabular}

From Table 5, the majority of students constituting 59\% indicated that one Kiswahili course book was shared among four students.22.3\% shared one book between three, while $18.7 \%$ of students shared one book among two students. This was so because majority of the students in day schools could not buy the required textbooks hence depended on those provided by the schools. This situation inhibits the teaching and learning of Kiswahili grammar section as learners must infer from the books and use them for assignments.

Students proportion of sharing books

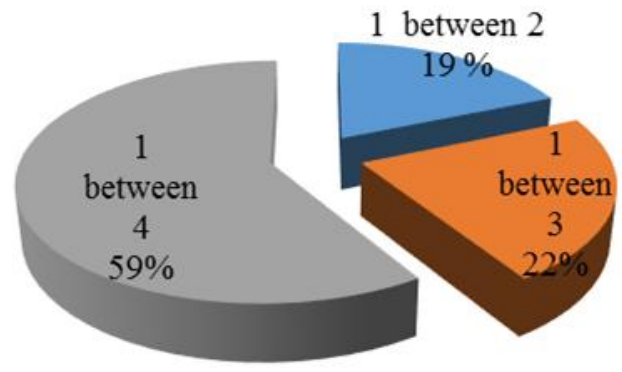

Figure 2 Showing proportions of sharing books

The researcher also sought to find out from principals if their schools had libraries. When they were asked if they had libraries, their responses were as shown in table 6

Table 6: Principals' responses on library availability $(n=12)$

\begin{tabular}{|l|l|l|}
\hline Item & Frequency & Percentage (\%) \\
\hline Have Library & 4 & 33.33 \\
\hline $\begin{array}{l}\text { Have a book } \\
\text { store }\end{array}$ & 8 & 66.67 \\
\hline
\end{tabular}

The results in Table 6 indicate that eight schools, constituting $66.67 \%$ had no libraries, while four schools representing $33.33 \%$ had well-stocked libraries. It was found that majority of the schools $(66.67 \%)$ were day schools which did not have enough resources to put up libraries thus had book stores. From the findings, it is clear that a larger percentage of schools didn't have adequate instructional resources.

Most schools especially day schools didn't have Kiswahili course books which are used daily in class. In fact, one text was shared among three learners, therefore impeding instruction in Kiswahili grammar. The significance of instructional resources cannot be underestimated; an assertion confirmed by Scheerens [38] who argues that availability of teaching resources enhances the effectiveness of a school as they are the basic things that can result in good academic performance.

School management styles are also found guilty as findings indicate that they don't always give priority to resources that directly affect academic performance when it came to allocating financial resources. Facilities like classrooms and libraries are also elusive in many schools. A fraction of the schools had swollen classes over and above the maximum of 45 set by the ministry of education, meaning teachers were unable to cope with the numbers when it came to individual attention. The findings are similar to those of Fabumni and Okore [39] from his study in Nigeria that class size affects performance and that the lower the class size, the higher the achievement and vice versa. More than twothirds of the schools did not have libraries, meaning that learners were denied the opportunity to interact meaningfully with books.

In summary, the study found that only four schools had libraries, while the other eight had book stores. Lack of 
Editon Consortium Publishing

Transforming Scholarly Publishing

\section{Editon Consortium Journal of Kiswahili (ECJKISW)}

Volume: 01 Issue: 01 | April -2019

ISSN: $2663-9289$ www.editoncpublishing.org

Githinji, D. G.; Lihanda, M. K., Editon Cons. J. Kiswahili. Double-Blind Peer Reviewed Journal

that necessary facility denied both students and teachers the opportunity to access reference materials and ample space, especially for students to do private studies when out of class. The analysis indicates that teaching and learning resources were inadequate in almost all the sampled schools especially those that fell in the County school category. Schools lacked the necessary textbooks like language course books, the few that were available students had to share in a ratio of one book to three learners.

School management styles were also found to impair schools' quest for impressive academic performance. The school's management did not allocate funds to those resources like books that directly affected student academic wellbeing and depended solely on government funds. School principals did not escape the blame because some of them could not send teachers for in-service courses because they had financial implications. That explains why many teachers had not attended in-service course though they had professional qualifications.

Class size was yet another factor that came out of the findings. From the results, some of the schools especially the extra county ones had swelled classes of above 50 students because they lacked enough classrooms. The increase in class size was occasioned by the introduction of free tuition, which led to massive enrollment in primary school with the number transcending to secondary schools. Teachers in such schools found it impossible to offer individual attention to learners who needed help. For some district schools, class size still remains a bother to them in a sense that many students had developed a habit of transferring from one school to the other; thus they could not maintain the average class size In addition, teachers in those schools were not able to keep track of their student academic progress making it difficult to improve on the instruction of Kiswahili grammar.

\section{Conclusion}

On school facilities and resources, many schools still lack the necessary instructional resources especially Kiswahili course books, thus impeding academic performance. From the study findings, many schools did not have enough classrooms forcing some to have swelled class sizes which were a burden to teachers. Conspicuously absent in schools were the libraries meaning that students lacked the necessary reference materials thus depending on a teachers' words.

The study came up with a recommendation that school authorities should make efforts, the county authorities, the Ministry of Education, and other stakeholders to provide enough facilities and resources like instructional resources, classrooms and libraries. 
Editon Consortium Publishing

Transforming Scholarly Publishing

\section{Editon Consortium Journal of Kiswahili (ECJKISW)}

Volume: 01 Issue: 01 | April -2019

ISSN: $2663-9289$ www.editoncpublishing.org

Githinji, D. G.; Lihanda, M. K., Editon Cons. J. Kiswahili. Double-Blind Peer Reviewed Journal

\section{Marejeleo/References}

[1] Republic of Kenya (2010). Constitution of Kenya. Nairobi: Government Printer.

[2] Ogechi, N., \&Ogechi, E. (2002). Educational publishing in African languages, with a focus on Swahili in Kenya. Retrieved from http://www.njas.helsinki.fi/pdf-files/vol.num2/ogechi.pdf.

[3] Kasfir (1976)

[4] Allan (1979)

[5] Republic of Kenya (1964-5). Kenya education commission report. Nairobi: Government Printer.

[6] ROK (1964-65)

[7] Sayoum, H. (1997). The language of education in Africa. The key issues. Journal of Pan-African studies.

[8] Mutiga, J. (2008). Nature and nurture, Tenets in the learning of Kiswahili as a second language in Kenyan bilingual system of education department of linguistics and African Language. The University of Nairobi.

[9] Bloom (1970).

[10] Musau (1999: 121).

[11] Kenya National Examination Council (2013: 13). The year 2012 KCSE Examination candidates' performance Report. Nairobi, Kenya

[12] Mugenda, O.M., \& Mugenda, A.G. (1999). Research methods. Quantitative and quantitative approaches. Nairobi: Acts Press.

[13] $\operatorname{ROK}(1988 a)$.

[14] Sallis E. (2002). Total quality management in education ( $3^{\text {rd }}$ edition) quicksilver Starting. Virginia USA Stylus.

[15] Republic of Kenya (2004). Ministry of education science and technology. Sessional paper on the policy framework for education, training and research (Meeting the challenges of the $21^{\text {st }}$ century). Nairobi: Government Printer.

[16] ROK (1988).

[17] Musau (2004).

[18] Ayoo S.J. (2002). An investigation of the factors influencing KCSE performance in Kisumu District. Unpublished. M.Ed. Thesis. The University of Nairobi.

[19] Raju (1973).

[20] Republic of Kenya (1981). Presidential working party report, Second University in Kenya. Nairobi: Government Printer.

[21] Mworia (1993).

[22] Mutua (2002).

[23] Kathuri, N. J. \& Pals, A. (1993). Introduction to Education research, Egerton University. Education Media Centre. Njoro, Kenya.

[24] Newton (1997).

[25] Adeogun, A. A. (2001:1-10). The Principal and financial management of Public Secondary Schools in Osun state. Journal of Educational system and Development. 
Editon Consortium Publishing

Transforming Scholarly Publishing

\section{Editon Consortium Journal of Kiswahili (ECJKISW)}

Volume: 01 Issue: 01 | April -2019

ISSN: $2663-9289$

www.editoncpublishing.org

Githinji, D. G.; Lihanda, M. K., Editon Cons. J. Kiswahili. Double-Blind Peer Reviewed Journal

[26] Eshiwani, G. S. (1975). Science and mathematics education in Kenya. Nairobi: Kenyatta University.

[27] Ayot, H. O. \& Briggs. (1992). Economics of education. Nairobi Education Research and publication.

[28] Mohammed (2010).

[29] WanyHaertel \& Walberg (1993).

[30] Dormam, M. (2008). The influence of environment on learners. Attitude in foreign Language setting.www.languageindia.com

[31] Nijihuis (2005).

[32] Goddard, R., Hoy, W., \& Hoy, A. (2000). Collective teacher efficacy: Its meaning, Measure and impact on students' achievement. American Educational Journal 37,497-507.

[33] Scheerens, J. (2003). Integrated models of educational effectiveness: Searching for the silver bullet in J. Scheerens., \& A.J. Visscher (Eds.), school effectiveness, Training effects: Enshede: Department of educational organisation and Management. Enchede: University of Twente, pp. $137-158$.

[34] Fabunmi, M., \& Okore, A. (2003). Analysis of the relationship between average class size and secondary school academic performance. Africa Journal of Educational Planning Policy Studies 1(2):107-115.

[35] Coombs (1970).

[36] Coleman, J., Campbell, E., Habson, C., Mepartland, J., Mood, A., Weinfall, F. et al. (1966). Equity of Education opportunity. Washington DC.

[37] Fuller (1985). Raising school quality in developing countries. What instruments Boost learning? Discussion paper, educational training. World Bank.

[38] Scheerens (2003). See note 33.

[39] Fabumni \& Okore (2000). 